TETYANA YERESKOVA,

Kyiv National Economic University named after Vadym Hetman (Kyiv, Ukraine)

e-mail: ta.ereskova@gmail.com,ORCID 0000-0001-7011-9590

OLEG MAZURYK,

Taras Shevchenko National University of Kyiv (Kyiv, Ukraine)

e-mail: oleg.mazuryk61@gmail.com, ORCID0000-0002-4531-7023

\title{
SOCIAL DIMENSION OF INNOVATION RESEARCH IN THE CONDITIONS OF SOCIAL TRANSFORMATIONS
}

\begin{abstract}
The article is devoted to understanding the social dimension of perception of innovations, which allows to determine the vector of perception of transformational changes in society. The urgency of the problem is due to the multicomponent processes of social transformations and the polyvariety of their consequences for social development. The theoretical foundations of scientific research are based on the analysis of theories of social transformations, stages of the "innovation life cycle", typology of subjects of perception of innovations existing in the socio-humanitarian discourse. The article substantiates the expediency of taking into account the methodological aspects of the study of innovation as a social process through the emphasis on the impact of social well-being of members of society on the perception of innovative changes as a result of socioeconomic, political, cultural transformations. A classification of innovations is proposed, depending on their perception by members of society ("recognized innovations", "fragmentary innovations", "marginal innovations", "antagonistic innovations", "rejected innovations"). The possibilities of their empirical classification were tested based on the results of the secondary analysis of the data of the annual monitoring "Ukrainian Society: Monitoring Social Changes" (Institute of Sociology of the National Academy of Sciences of Ukraine). As a result of the research it was possible to determine the basic indicators of perception of social reality by members of Ukrainian society in periods of social transformations ("satisfaction with one's position in the period of social transformations", "ability to live in new social conditions", "satisfaction with one's own life"); to trace their dynamics in the periods defined in the article by the authors as stages of social transformations $(1994,2004,2014,2020)$. According to the authors, it is during these periods that certain socio-cultural changes, which determine the vital activity of Ukrainian society, have been initiated. It is concluded that indicators of social well-being of members of society should be analyzed and taken into account when planning innovations, because it allows to predict and consider potential social reactions not only to the emergence of innovations introduced as part of social transformation, but also their level of social support in conditions of social transformations.
\end{abstract}

Key words: innovation, social transformations, social dimension, social process, innovation life cycle, indicators of social well-being.

\section{Introduction}

Innovation as a process of creating and implementing new developments is not a new object in scientific discourse. However, modern conditions are changing the perception of the role of innovation in the functioning of civil society, especially in the period of social, economic and political transformations (Skvorets, Kudinov, 2021). In classical socio-humanitarian discourse, there are several views on the interpretation of the concept of "innovation". It was considered as an economic tool (J. Schumpeter, P. Drucker), as a result (G. Tarde), as a kind of social interaction ( $R$. Merton), as a process (P. Sorokin). This tradition (multi-vector perception of innovation) has continued to this day (Santo, 2004; Sandyha, 2005; Lutsykiv, 2010; Kuchko, 2011; Geets et all, 2015; Hasselbalch, 2018;
Kolishchuk, 2018). We do not consider these approaches to be mutually exclusive and do not attempt to conduct indepth analysis. Our goal is to expand the methodological approaches to the study of the social dimension of innovation. We focus on identifying the factors that influence society's perception of the innovation process. Based on this, we consider it appropriate to pay attention to the understanding of innovation as a social process, the process of formation, initiation and implementation of certain tools and activities that affect the vector of society, the dynamics of social change. That is why the idea of the article is, firstly, caused by the search for methodological foundations for the study of innovation as a social process in the period of social transformation; secondly, by the definition of indicators that would testify to the de- 
gree of readiness of members of society to perceive certain innovations, the need to predict the dominance of certain forms of innovation and types of innovation subjects.

\section{Research methods}

The development of a methodological approach to the study of innovation as a social process was based on the theories of social change by P. Sztompka, theory of social transformation by $\mathrm{O}$. Kutsenko and concepts of social transformation by E. Golovakha, of social, cultural and political changes by R. Inglehart (Shtompka, 2007, 2020; Kutsenko, 2007; Inglehart, Arbor, Welzel, 2012; Golovakha, 2016). Empirical testing was conducted using the method of secondary analysis of the results of national annual monitoring surveys (1992-2020) of the Institute of Sociology of the National Academy of Sciences of Ukraine, which are publicly available (Ukrayinske suspilstvo.., 2020). We understand that our approach has certain research limitations, which are the debatability of the application of the concept of "social transformation" in the context of the development of Ukrainian society. One cannot state with certainty whether we should consider specific periods (years) that caused (albeit for some time) significant socio-political changes that influenced the emergence of innovations in the functioning of Ukrainian society as social transformations; or these are only certain stages on the way to the formation of the social system "Ukrainian state" as a European democratic entity, the innovative component of which is too early to say. However, during the scientific research we relied on the interpretation of social transformations by E. Golovakha, who emphasizes that any social transformation is a process of significant, profound social change, which, unlike transit, does not have a predetermined goal, because these transformational changes are the result of forced unexpected changes (Golovakha, 2016). In our opinion, this aptly illustrates the realities of Ukrainian society since the declaration of independence.

\section{Result and Discussion}

In his work "Social and Cultural Dynamics", P. Sorokin gave, in our opinion, a classic definition of the social process: "The process means any kind of movement, modification, transformation..., in short, any change in the object under study over a period of time, whether it is a change in its place in space, or a modification of its quantitative and qualitative characteristics" (Sorokin, 2016: 98). Indeed, in socio-humanitarian discourse, social processes are understood as a series of phenomena of human interaction with each other, or a series of phenomena occurring in the organization and structure of groups that change relations between people or relations between constituent elements of community. A series of social phenomena can be understood as a process if it preserves its identity over time, which allows to distinguish it from other series, if previous phenomena cause, at least in part, subsequent phenomena and if they cause a certain homogeneous state of affairs (Beck, 2000).

If innovations are considered as a process, then they mean the process of creating, disseminating and using innovation. In our opinion, innovation is a long series of interactions between the innovator, innovators and the social environment. This series retains its identity with the help of the identity of the society in which the innovation is implemented. The reaction of society to the introduction and dissemination of innovations is to some extent due to the existing socio-cultural environment, resulting in a certain society's attitude to innovation, which is measured in the interval from full acceptance to complete rejection.

The procedural nature of innovations is also evidenced by the possibility of determining their life cycle. The concept of "innovation life cycle" is used by $P$. Sztompka. What is meant is the period of time between the moment when an innovation is put forward and the time when it becomes generally accepted in society, replacing certain prescriptions, ideas and norms that prevailed before. This process can be divided into five stages: the emergence of innovation; identification of innovation; innovation filtering; diffusion of innovation; dissemination of innovation (Sztompka, 2020). Each stage is totally random - the process may continue, and may slow down, reach the final phase of formation or stop halfway. Let us consider the stages of innovation in more detail.

First, there is the initiation of innovation, i.e. the emergence of the idea and its materialization. We are not interested in this stage within the research problem, so we shall not dwell on it in this article. The next stage is to identify the innovation. This is the moment that divides innovations into private and public ones. That is, innovation can remain private, completely peculiar to this stage, and attempts to make it public may be unsuccessful for a long time. Or the innovation becomes public by making it accessible to other people. But even if innovations become "famous", this does not mean an immediate social return on them. Innovations can be either accepted or rejected by society. At this stage, the main role is played by selection criteria, selectors, which prevent some innovations from spreading and allow others to break through. Such selectors are: compatibility of innovations with socio-cultural factors (culture, traditions, values, norms, habits of people); the degree of difficulty to understand and use innovation, its profitability; timeliness of innovations, degree of population's involvement; degree of risk.

It is well known that the attitude of society to innovation is significantly influenced by the knowledge and skills, values and norms of specific individuals involved in this innovation. The availability of a wide range of knowledge and skills affects a more positive perception of the new, and those who know and are skillful "from here to here" often resist the new. To this are added differences in values and norms - for some people the new is much more valuable than the old, curiosity is the norm of their behavior, and for others the new is associated primarily with danger, their norm is to avoid the new, stay in within the proven old. Based on this, the subjects of innovation are distinguished, which are divided into five groups (Rogers, Singhal, Quinlan, 2009):

- "innovators" (ready to develop, propose and feel something new, test ideas with some risk);

- "early adopters" (perceive new ideas after certain considerations);

- "early majority" (quickly perceive innovations, but very rarely take leadership roles in the process of their promotion);

- "late adopters" (accept innovations only under the pressure of the majority); 
- "laggards" (do not agree with the implementation of any innovations, the perception of innovation is only when it becomes a tradition, generally accepted).

The dominance of certain subjects of innovation in society depends in some way on the mechanism of innovation filtering formed in the socio-cultural environment. In this regard, the following classification of innovations can be proposed: constructive innovation (a new idea arises on a certain foundation of traditions, but is a breakthrough combination of known components); functional innovation (the predominance of a view of familiar ideas which is conceptually different from the traditional one, there is a formation of a new quality of familiar things); stylistic innovation is considered in combination with a stable emotional factor (an unusual representation of trivial ideas is formed, which is, in fact, an illusion of novelty); open innovation (ideas that provide the possibility of additional personification may be trivial alone, but acquire a unique character when interacting with a particular individual).

Analyzing the above, we can identify a certain methodological algorithm for the study of innovation as a social process.

Firstly, when implementing innovations, it is necessary to carefully assess the situation and anticipate the potential of each idea, i.e. the timeliness of innovation should be ensured. It is undeniable that innovation is most prevalent in societies where the level of wealth and confidence in the future is the highest. Within each particular society, innovations are most prevalent among the strata who are more confident in the future than others (for example, the wealthiest and most educated strata). The strata whose position is the least reliable will emphasize the habitual priorities of survival (Inglehart, Arbor, Welzel 2012).

Secondly, in determining innovation, the social behavior of individuals should be taken into account. This approach underlies the typology according to which there is a slowed innovation (has minimal impact on patterns of behavior); dynamically developing innovation (new and traditional forms of behavior are contained in the personal structure of individuals equally); fleeting innovation (quickly approves new patterns of behavior). In this sense, the value of innovation is that it forms a significant amount of previously non-existent objects and actions, characterized by the expected relative advantage of innovation. Innovations that have a significant number of obvious advantages are introduced most rapidly. The benefits of innovation are shown to potential "consumers" during its demonstration. There are two types of demonstration of innovation: demonstration of use or methodical demonstration, the essence of which is to show the process of operation of innovation, and demonstration of the result which is showing the benefits of using innovation. After the demonstration of innovations, depending on public awareness of final results of innovations, they can be divided into three types: evident, hidden and "boomerang innovations". Evident innovations are changes the meaning and consequences of which are realized by members of society; hidden innovations are changes the meaning of which is not realized by members of society, "boomerang innovations" are innovations the content of which the population is aware of, but the consequences are not clear for the majority of the population (Sztompka, 2007).

Thirdly, the level of public involvement in various stages of the innovation process plays an important role.
According to this criterion, there are administrative innovations (members of society do not affect the innovation process) and collective (participatory) innovations (members of society determine the innovation process). It is thought that the first type of innovation is more effective because it reduces the level of resistance to change, and increases the flow of new proposals to improve the quality of innovation. Participatory innovations are implemented when people feel that they will be rewarded for their efforts. In this way, innovation can be accepted by the imposed interests of those in power, the means to support norms and values. On the basis of the above innovations can be classified into implemented "top-down" and "bottom-up".

Fourthly, the characteristic of radicality or routinism of innovation is also extremely important. The greater the risk and novelty of the proposed transformations is, the higher the degree of their radicalism is and the slower they are perceived by society (Khan, 2017). After all, most of the risks posed by the success of scientific and technological modernization are not perceived directly by the human senses. These risks exist only in the form of knowledge about them. Hence, professionals responsible for determining the degree of riskogenics of new technologies and technical systems, as well as the media, which disseminate knowledge about them, take key social and political positions (Beck, 2000). Thus, at this stage of the innovation process one can face the logical (rational), psychological (emotional), social, cultural types of resistance to change. Logical resistance arises from the need to spend a lot of time and effort to adapt to change. With psychological resistance, people may be afraid of the unknown, distrust the leadership, feel the threat to their safety, self-esteem. The social resistance is conditioned by the influence of the group on the individual. Cultural reasons for resistance to change are related to changes in traditions, values and social norms active in society.

Fifthly, if innovations successfully "break through" all filtering mechanisms and reach the general public, their diffusion or dissemination, in other words, the adaptation of changes to the socio-cultural environment, deep, longterm rooting of innovation in the regulatory system begins (i.e. transformation of what was once a break with the convention into a new convention, what was a rejection of tradition, a rupture of tradition - into a new tradition, all what was nonconformism - into mandatory rules of conduct) (Sztompka, 2007; Rogers, Singhal, Quinlan, 2009).

As we can see, at each stage of formation and implementation of innovations, there is a variety of types of innovations, but based on existing classifications of innovations depending on different criteria, we will make an author's attempt to classify innovations according to public perception and consequences for society.

Thus, in our opinion, we can distinguish:

- "recognized innovations" that have received public recognition, are supported by a system of socio-cultural values and social needs and, as a result, have become widespread and applied;

- "fragmentary innovations", when changes are accepted, but affect only some individual component that occupies a peripheral position in the structure, and the changes do not have any other responses and consequences for society; 
- "marginal innovations" that are accepted by society and become widespread, however, did not lead to the expected results but to the accidental transformation of certain elements of the structure (some individual norms and values, institutions, roles, etc.);

- "antagonistic innovations", when the resistance is so great that people react too strongly and try not only to maintain the status quo, but also to finally change the structure in the opposite direction. That is, the introduction of innovation leads to opposite results;

- "rejected innovations", when changes cause resistance until the complete destruction of innovations.

With the help of sociological data, we have tried to determine the potential format of perception of the types of innovations we have identified in Ukrainian society during the socio-economic and political transformational changes. References to the results of national annual monitoring surveys of the Institute of Sociology of National Academy of Sciences of Ukraine "Ukrainian Society: Monitoring Social Change", conducted since 1992, provide an opportunity to analyze the dynamics of changes in social behavior of Ukrainian society, their attitude to certain transformations that take place in society. As an illustration, we have analyzed the empirical data for 1994, 2004, 2014 and 2020. In our opinion, it was during these periods that significant social transformations took place in the life of Ukrainian society: 1994 - the fourth year of independence (period of reflection, summarizing certain results of the process declaration of independence of Ukraine); 2004 - Orange Revolution; 2014 - Revolution of Dignity; 2020 - the year after the election of the President of Ukraine, which caused a certain change in the internal and external public rhetoric of Ukrainian politics, and, as a consequence, the initiation of "new" transformational processes of development of Ukrainian society. To understand the social situation (through the eyes of
Ukrainians), we chose the answers of respondents on three markers of social well-being "satisfaction with their position in society today", "ability to live in new social conditions", "satisfaction with their own lives". In our opinion, these indicators record a kind of "given" and conditions of perception of members of Ukrainian society of social reality, in which certain socio-economic and political innovations were introduced.

During the analysis of the data, we combined the responses of the respondents in a positive and negative direction (as we were only interested in the general connotation of the respondents' assessments). In our opinion, this is expedient, because we are interested not so much in determining the level of satisfaction or dissatisfaction, but in the general trends of the impact of social transformations on everyday life. We transformed the answers "rather satisfied" in positive assessments (see Fig. 1); answers "rather dissatisfied" in negative assessments (see Fig. 2); the answers "it is difficult to say satisfied or not" were not transformed in terms of content (see Fig. 3).

As can be seen, in the years mentioned by us, the number of respondents' positive assessments of their own reflection on the perception of themselves against the background of social transformations is increasing. However, we would like to draw attention to the fact that, firstly, the events that accompany the process of "social transformation", in some way, contribute to a kind of "stabilization", "fixation" of social well-being (as evidenced by the statistical distribution of data for 2014, 2020 years). Here, perhaps, it is appropriate to talk about a certain habituation of members of Ukrainian society to a certain "regularity" of social transformations in Ukrainian society. Secondly, the tendency of social subjects to adapt to life in the conditions of social transformations is growing, and, as a result, satisfaction with one's own life is growing.

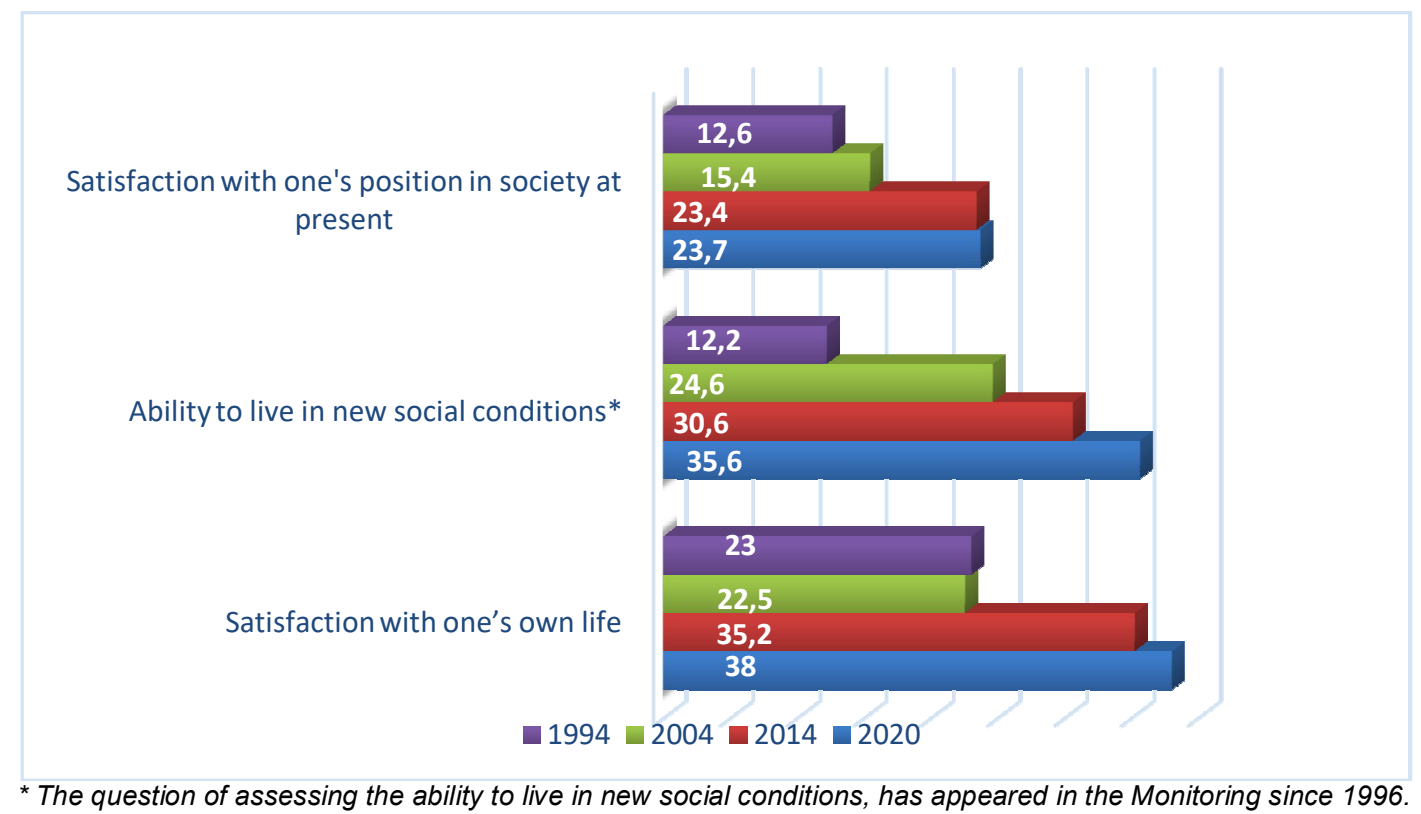

Fig. 1. Distribution of positive assessments of the social well-being of respondents (in \% and who answered the relevant questions) according to indicators of perception of social reality in the period of social transformations.

Source: developed by the authors based on (Ukrainian Society.., 2020: 486, 488). 
The above general trends are confirmed by the statistical distribution of negative assessments of selfsatisfaction of respondents on our selected indicators of perception of social reality. We mean a clear tendency to reduce them by all indicators.

The distribution of respondents' answers, who cannot unambiguously determine their own satisfaction with the indicators of the impact of periods of social transformations, indicates that during social transformations a certain social community is formed, whose members demonstrate being in a state of social uncertainty. Interestingly, it turned out to be statistically constant (the difference in the distribution of interest for each indicator, regardless of the time period, is up to $3.5 \%$ ). Although there is a surge in the indicator "satisfaction with one's life in society at present" in 2014 and 2020 compared to 1994 and 2004, the statistical difference within these periods also does not exceed $3.5 \%$.

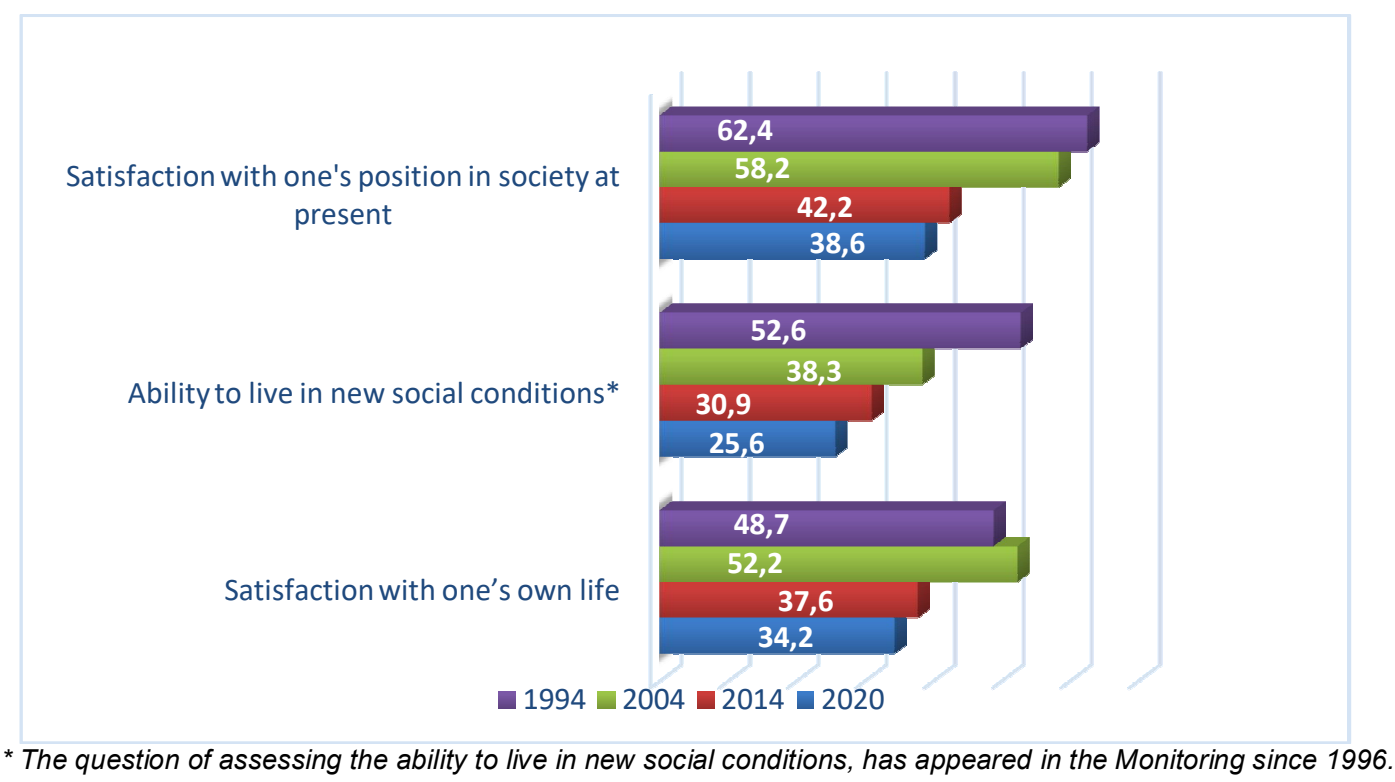

Fig. 2. Distribution of negative assessments of the social well-being of respondents (in \% and who answered the relevant questions) according to indicators of perception of social reality in the period of social transformations.

Source: developed by the authors based on (Ukrainian Society.., 2020: 486, 488)

Satisfaction with one's position in society at present

Ability to live in new social conditions*

Satisfaction with one's own life

$1994-2004=2014-2020$

\section{- 199}

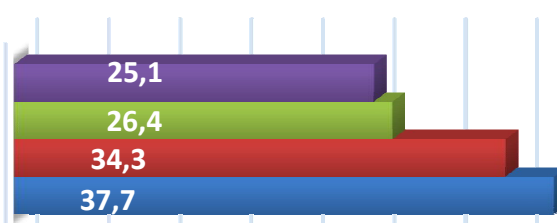

31,8

32,7

34,2 31,9
* The question of assessing the ability to live in new social conditions, has appeared in the Monitoring since 1996.

Fig. 3. Distribution of assessments of respondents (in \% and who answered the relevant questions) who could not determine the answer to social well-being with the indicators of perception of social reality in the period of social transformations.

Source: developed by the authors based on (Ukrainian Society.., 2020: 486, 488). 
Also, the attitude to innovation in the period of social transformations depends on the understanding of what processes are taking place in society as of now (we mean the stages that we have defined as "social transformations" in the development of Ukrainian society). This knowledge is necessary for members of society in order to assess the necessity, timeliness, usefulness, effectiveness of the proposed innovations (regardless of who initiates them). In our opinion, this correlates with the ability to obtain reliable information. The methodology of secondary analysis, again, allowed us to "compress" the data of the Monitoring in the direction of connotation of answers (positive, negative) of respondents. For example, we interpreted the respondents' answer options "slightly improved / significantly improved" as "positive assessment", answer options "slightly worsened / significantly worsened" were interpreted as "negative assessment", we did not change answer options "remained unchanged" and "did not answer". This allowed us to record the dynamics of respondents' perception of their own ability to obtain reliable information about what is happening in the country and the world (see Fig. 4).

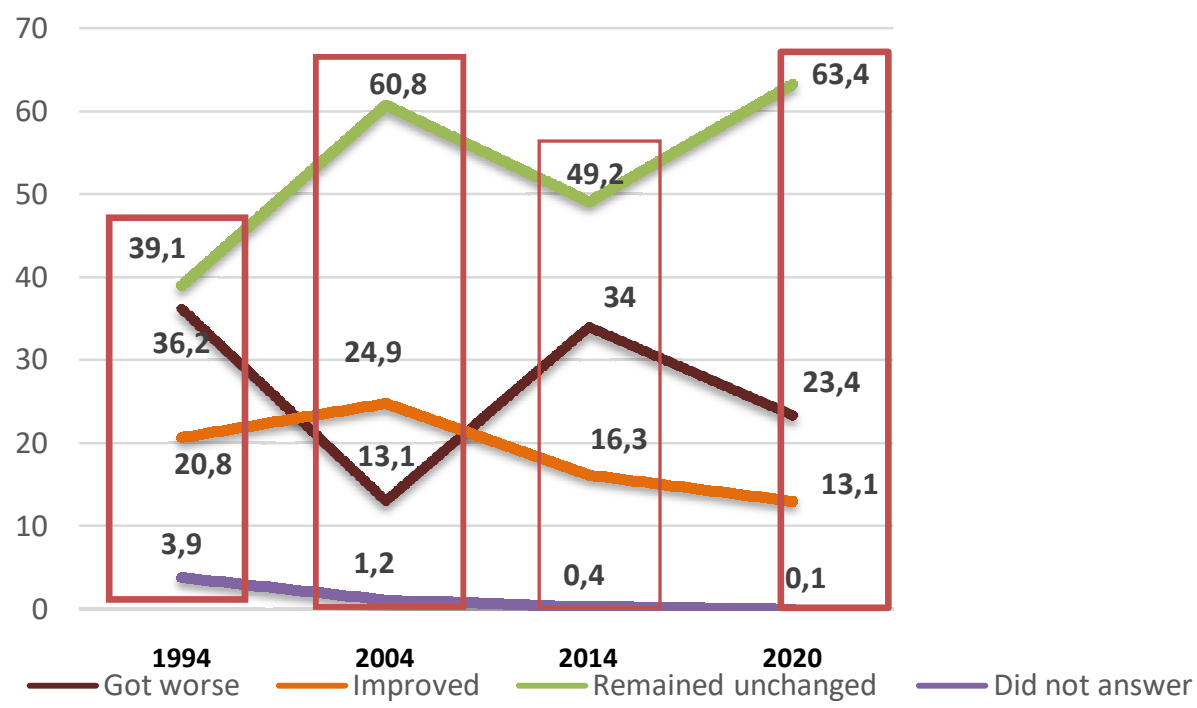

Fig. 4. Distribution of answers of respondents (in $\%$ and who answered)

to questions about the possibility of obtaining reliable information about what is happening in the country and the world for the last 12 months.

Source: developed by the authors based on (Ukrainian Society.., 2020: 527).

Empirical data show that during social transformations, the possibility of obtaining reliable information about the processes taking place, firstly, remains unchanged, and secondly, there is a deterioration of the situation (only in 2004 there was a surge of positive assessments). This is due to both objective and subjective factors, namely: the initiators of social transformations cannot or do not want, or have no opportunities to provide a process of systematic support (recognition) of social change by community; information received by community is considered a priori unreliable by members of society and they respond to it accordingly; the members of society themselves are indifferent to the search, critical understanding of the information that comes to them. This indirectly confirms our reflections on the potential attractiveness of certain types of innovations for members of Ukrainian society (such as "fragmentary" and "marginal") in a period of social transformation.

\section{Conclusion}

The proposed methodological view of innovations as a social process allows to determine certain types of innovation, depending on their potential perception by members of society in the period of social transformation and to make an empirical measurement of the dependence of innovation on the socio-cultural environment. Analyzing empirical data on the social conditions of Ukrainians in periods of social transformation, we have tried, based on the author's typology of innovations, to identify socially conditioned types of innovations that are perceived during social transformations. Thus, we can state that in the period of social transformations, members of society are potentially ready to accept innovations (as a result or consequence of transformation processes). However, there is a selectivity of their perception. In such periods, innovations that do not require public recognition (we mean, that are not supported by the renewal of the system of socio-cultural values and social needs in the context of social transformations) are perceived. Therefore, the introduction of "recognized innovations" (which become widespread and widely used) in such periods do not have adequate perception in society. This is due to the fact that the main task of social actors is to adapt themselves to the changes that have caused social transformations, and to adapt these changes to their own daily practices. That is why the most perceived in this period are "fragmentary innovations" and "marginal innovations", which affect either certain components of the life of society (those that, in the opinion of social actors, do not directly affect their daily lives), or do not lead to the expected results, although they may cause random individual changes in some structural elements of society (spheres, groups, communities, institutions, etc.). However, it should be noted that in the period of social transforma- 
tions, most members of society do not perceive such types of innovations as "antagonistic" and "rejected". In other words, the tendency to adapt quickly to social change (in the context of "learning to live in new conditions so as not to worsen one's life and condition") minimizes and in some way blocks open resistance or the desire (at any cost) to maintain the current state of affairs.

It is obvious that not all innovations are accepted and disseminated in the period of social transformations, because they do not find the necessary socio-cultural conditions in which they are recognized and accepted. That is why, in our opinion, in the period of social transformations it is expedient to use additional types of innovations. Here it is interesting to see the existence of additional types of innovations that are created for easy implementation of conventional innovations. These additional types are preventive and instrumental innovations. Preventive innovations are ideas or decisions that are produced in order to avoid certain consequences or events in the future. Instrumental innovations are used to create conditions for easier implementation of other innovations. The main direction of our further research is, based on the proposed methodology of research of innovations as a social process, to empirically determine the typification of innovation subjects in the social structure of society ("innovators"; "early adopters"; "early majority"; "late adopters" and "laggards") in order to identify the so-called "centers of social activity" of perception / non-perception of innovation in the period of social transformation. In our opinion, this will deepen the understanding of the essence of the perception of social transformations as an environment in which members of Ukrainian society should function in the future.

\section{REFERENCES}

Beck, W. (2000). Obshchestvo riska. Na puti ko vtoromu modernu. Moscow: Progress -Tradition, 384 p. (In Russian).

Geets, V.M. (ed.) at all (2015). Innovative Ukraine 2020: national report. Kyiv: NAS of Ukraine, 336 p. http://ief.org.ua/wpcontent/uploads $/ 2015 / 07 / \% \mathrm{D} 0 \% 86 \% \mathrm{D} 0 \% \mathrm{BD} \% \mathrm{D} 0 \% \mathrm{BD} \% \mathrm{D} 0$ \%BE\%D0\%B2\%D0\%B0\%D1\%86\%D1\%96\%D0\%B9\%D0\% BD\%D0\%B0-\%D0\%A3\%D0\%BA\%D1\%80\%D0\%B0\%D1\%97\%D0\%BD\%D0\%B0-2020++.pdf (In Ukrainian).

Golovakha, E. (2016). Ukrayinske suspilstvo: shlyakhy transformatsiyi. Ukrainian Sociological Journal. № 1-2 http://sgsofia.com.ua/ukr-suspilstvo-slyahi-transformazii]. (In Ukrainian).
Hasselbalch, J. A. (2018). Innovation assessment: governing through periods of disruptive technological change Journal of European Public Policy, Volume 25, Issue 12 https://www.tandfonline.com/doi/full/10.1080/13501763.2017.1363805

https://www.cambridge.org/core/books/modernization-culturalchange-and-democracy/4321210B04C63808615846DB0E3EEC34\#fndtn-information

Inglehart, R., Arbor, A., Welzel, C. (2012). Modernization, Cultural Change, and Democracy. The Human Development Sequence Cambridge University Press,

Khan, Sana Akbar (2017). Consumer Innovation Adoption Stages and Determinants Department of Management, Università Ca' Foscari Venezia Working Paper No. 2017/03, https://ssrn.com/abstract=2934916 or http://dx.doi.org/10.2139/ssrn.2934916

Kolishchuk, O. (2018). Analiz klasyfikatsiy innovatsiy za rivnem novyzny. Food Industry Economics, 10(3). https://doi.org/10.15673/fie.v10i3.1062 (In Ukrainian).

Kuchko, Ye. (2011). Sotsialnyye innovatsii: podkhody k opredeleniyu i klassifikatsii. Visnyk Kharkivskoho natsionalnoho universytetu imeni V.N. Karazina. Ser.: Sotsiolohichni doslidzhennya suchasnoho suspilstva: metodolohiya, teoriya, metody. № 941: 27-33. (In Ukrainian).

Kutsenko, O. (2007). Ukraina $v$ transformatsionnykh protsessakh: Quo vadis? Sotsiologiya: teoriya, metody, marketing. 1: 18-32. http://dspace.nbuv.gov.ua/handle/123456789/90318 (In Ukrainian).

Lutsykiv, I. (2010). Ekonomichna sut innovatsiynoyi diyalnosti. Halytskyy ekonomichnyy visnyk. 2 (27): 89-95 https://galicianvisnyk.tntu.edu.ua/?art=675 (In Ukrainian)

Rogers, M., Singhal, A., Quinlan, M. (2009). Diffusion on innovations http://utminers.utep.edu/asinghal/Book\%20Chapters/Rogers-Singhal-Quinlan-2009-DOIStack\%20and\%20Salwen.pdf

Sandyha, O. (2005). Innovatsiyi: sotsialno-filosofskyy analiz. Multyversum. Filosofskyy almanakh. 48: 43-54. (In Ukrainian).

Santo, B. (2004). Sila innovatsionnogo samorazvitiya. Innovatsii. 2: 5-15. http://iee.org.ua/ru/publication/24/ (In Russian).

Shtompka, P. (2007). Sotsiologiya sotsialnykh izmeneniy. Moscow: Direkt-Media. 828 p. https://biblioclub.ru/index.php?page=book\&id=26598 (In Russian).

Shtompka, P. (2020). Sotsiolohiya. Analiz suspilstva. Lviv: Kolir PRO, 800 p. (In Ukrainian)

Skvorets, V. \& Kudinov, I. (2021). Socio-cultural transformation in post-soviet Ukraine. Skhid, 1 (1(2), 43-51. https://doi.org/10.21847/1728-9343.2021.1(2).236142

Sorokin, P. A. (2016). Sotsialnaya i kulturnaya dinamika. Moscow: Astrel, 964 p. (In Russian).

Ukrayinske suspilstvo: monitorynh sotsialnykh zmin (2020). Zbirnyk Naukovykh prats. 7(21). Kyiv: Institute of Sociology of the National Academy of Sciences of Ukraine 546 p. (In Ukrainian).

\section{Тетяна Єрескова,}

Київський начіональний економічний університет імені Вадима Гетьмана (м. Київ, Украӥна)

e-mail: ta.ereskova@gmail.com, ORCID 0000-0001-7011-9590

Олег Мазурик,

Київський національний університет імені Тараса Шевченка (м. Київ, Україна)

e-mail: oleg.mazuryk61@gmail.com,ORCID 0000-0002-4531-7023

\section{СОЦІАЛЬНИЙ ВИМІР ДОСЛІДЖЕННЯ ІННОВАЦІЙ В УМОВАХ СУСПІЛЬНИХ ТРАНСФОРМАЦІЙ}

Стаття присвячена осмисленню соціального виміру сприйняття інновацій, що дозволяє визначити вектор сприйняття трансформаційних змін у суспільстві. Актуальність проблеми обумовлена багатокомпонентністю процесів суспільних трансформацій та поліваріантністю їх наслідків для суспільного розвитку. Теоретичні підвалини наукового пошуку ґрунтуються на аналізі теорій суспільних трансформацій, стадій «життєвого» циклу інновацій, наявній у соціогуманітарному дискурсі типології суб'єктів сприйнят- 
тя інновацій. Обґрунтовується доцільність урахування методологічних аспектів дослідження інновацій як соціального процесу через акцентуацію впливу соціального самопочуття членів соціуму на сприйняття інноваційних змін як результату соціально-економічних, політичних, культурних трансформацій. Пропонується класифікація інновацій, залежно від їх сприйняття членами соціуму («визнані інновації», «фрагментарні інновації», «маргінальні інновації», «антагоністичні інновації», «відторгнені інновації»). Проведена апробація можливостей їх емпіричної класифікації за результатами вторинного аналізу даних щорічного моніторингу «Українське суспільство: моніторинг соціальних змін» (Інституту соціології НАН України). У результаті дослідження вдалося визначити базові індикатори сприйняття соціальної реальності членами українського суспільства у періоди суспільних трансформацій («задоволеність своїм становищем у період суспільних перетворень», «вміння жити у нових соціальних умовах», «задоволеність власним життям»); простежити їх динаміку у періоди, які у статті визначені авторами як етапи суспільних трансформацій (1994, 2004, 2014, 2020). На думку авторів, саме в ці періоди ініціюються певні соціокультурні зміни, які детермінують життєдіяльність українського соціуму. Зроблено висновок, що показники соціального самопочуття членів соціуму доцільно аналізувати та враховувати під час планування інновацій, бо це дозволяє спрогнозувати та врахувати потенційні соціальні реакції не лише на появу інновацій, що запроваджуються як складові процесу суспільних перетворень, а й рівень їх соціальної підтримки в умовах суспільних трансформацій.

Ключові слова: інновація, суспільні трансформації, соціальний вимір, соціальний процес, життєвий цикл інновацій, індикатори соціального самопочуття.

() Tetyana Yereskova, Oleg Mazuryk

Надійшла до редакції: 20.08.2021

Прийнята до друку: 20.09.2021 